\title{
Hygienic Quality Assessment Of Pork Carcasses obtained In Industrial And Traditional Slaughtering Units
}

\author{
Oana Lucia REGET*, Alexandra TĂBĂRAN, Sorin Daniel DAN, Ionuţ CORDIŞ, Dana Liana PUSTA, Marian \\ MIHAIU
}

${ }^{1}$ Faculty of Veterinary Medicine, University of Agricultural Sciences and Veterinary Medicine, Mănăştur Street, no.3-5, Cluj-Napoca, Romania

*corresponding author: oanalucia88@yahoo.co.uk

Bulletin UASVM Veterinary Medicine 74(1) / 2017,

Print ISSN 1843-5270; Electronic ISSN 1843-5378

DOI:10.15835/buasvmcn-vm: 12500

\begin{abstract}
In March 2016, the microbiology laboratory of the Faculty of Veterinary Medicine Cluj-Napoca, 3 type of antiDespite the fact that many types of foods can be sources of food borne illnesses, meat and meat products are very important sources of infection in people with a wide variety of pathogens that cause food poisoning.

The aim of this study was to conduct an assessment of meat hygienic quality and configuration by assessing the microbial load and the presence of pathogens.

The material under investigation was represented by 40 samples of muscle tissue from pork carcasses collected in stages, between 2015-2016, from slaughtering units both from the traditional system and the industrial system. Samples were analyzed at the Department of Food Safety and Control of Animal Origin Products.

Total viable count in samples taken from the carcasses, in 2016 presented values similar to those in 2015, ranging from a minimum of $2.74 \pm 0.36 \mathrm{log} \mathrm{cfu} / \mathrm{cm} 2$ in January and December and a maximum $3.73 \pm 1.13 \log$ cfu / $\mathrm{cm}^{2}$ recorded in February, without showing significant differences between the samples processed in the studied period $(\mathrm{p}>0.05)$. The results regarding contamination of swine carcasses (surface) with germs from Enterobacteriaceae family were non-compliant, exceeding the maximum permissible limit of $3.0 \log \mathrm{cfu} / \mathrm{cm}^{2}$ in all 12 samples examined (30\%). In what regards the molecular testing for the confirmation of E. coli, a total of 6 samples were positive, but none of this tested positive for the presence of the toxicity genes (Stx1, Stx2).

In the case of the samples taken from pork carcasses the results regarding germs from Enterobacteriaceae family were non-compliant, $29.16 \%$ of the samples examined during the period under study were found to exceed the maximum limit, which showed deficiencies regarding the hygiene requirements.
\end{abstract}

Keywords: hygienic quality, pork, slaughterhouse

\section{INTRODUCTION}

Food pathogens annually cause millions of food born diseases, most of them resulting in cronic diseases or even death of the consumer. The globalization of the food chain also led to increased risks of foodborne illnesses spreading beyond international barriers. The main food that can pose life-threatening in consumer are: meat, meat products, fish, eggs and dairy products. Among this there are: Salmonella spp., Campylobacter jejuni/coli, Yersinia enterocolica, E. coli verotoxigenic Listeria monocytogenes (Algino et al., 2009). The most common chain of events leading to diseases that are caused by meat consumption involves meat supplying animals that are healthy but carrying pathogens that are 
Tab. 1. The primers used in the detection of Verotoxigenic E.coli.

\begin{tabular}{ccccc}
\hline Gene & Primer sequence (5'- 3') & Lenght (bp) & $\begin{array}{c}\text { Alin } \\
\text { temp. } \\
\left(\mathbf{~}^{\circ} \mathbf{C}\right)\end{array}$ & Reference \\
\hline $\begin{array}{c}\mathbf{2 3 S} \\
\boldsymbol{E . c o l i}\end{array}$ & $\begin{array}{c}\text { F: AAGGAATCACCTTGCAGATAAACTC } \\
\text { R: TTTCCGAGTACATTGGCATCGT }\end{array}$ & 736 & 56 & Malorny et al., 2004 \\
\hline Stx1 & $\begin{array}{c}\text { F: CGC TGA ATG TCA TTC GCT CTG C } \\
\text { R: CGT GGT ATA GCT ACT GTC ACC }\end{array}$ & 302 & 60 & $\begin{array}{c}\text { Blanco } \text { et al., } \\
\text { 2004 }\end{array}$ \\
\hline Stx2 & $\begin{array}{c}\text { F: CTT CGG TAT CCT ATT CCC GG } \\
\text { R: CTG CTG TGA CAG TGA CAA AAC GC }\end{array}$ & 516 & 60 & $\begin{array}{c}\text { Blanco } \text { et al., } \\
\text { 2004 }\end{array}$ \\
\hline
\end{tabular}

subsequently transferred to humans through production, handling and consumption of meat and meat products (Bonardi et al., 2008).

Universal methods for assessing the microbiological hazards posed by total viable count and main pathogenic bacteria (E. coli, Salmonella spp., psihrotrofic bacteria) they are still less developed in our country.

\section{MATERIALS AND METHODS}

The material under investigation was represented by 40 samples of muscle tissue, taken from carcasses (as it will be described further) harvested in stages, between 2015-2016, from meat processing units both from the traditional system and industrial system. From the pig carcasses samples were taken from four different areas: chest, flank, cervical region, thigh. Sampling was done randomly, given that they come from carcases obtained both at the beginning and at the end of slaughtering line, on different days of the week, respecting the norms.

From the surface of the muscle tissue were taken superficial flaps with a thickness of 2-3 $\mathrm{mm}$, totaling an area of $100 \mathrm{~cm}^{2}$. Samples were placed in sterile petri dishes with a diameter of $15 \mathrm{~cm}$ and transported at $4^{\circ} \mathrm{C}$ to the laboratory of Inspection and Control of Animal Origin Products discipline from the Faculty of Veterinary Medicine Cluj-Napoca, where they were introduced in work immediately.

The isolation of the pathogens present on the carcasses surface was made on account of the standardize methods in conformity with the Reg. (EC) 1441/2007: the Enterobacteriaceae identification respecting SR ISO 21528/2007, the total viable count (TVC) following SR ISO $4833 / 2003$ the identification of E.coli respecting SR ISO 16649/2007.
Bacterial DNA extraction, necessary to perform the PCR technique, followed the basic steps described by Yang et al. (2008), with some particularities. Briefly, $150 \mu \mathrm{l}$ of Chelex (10\%) reagent (BioRad) was addes in Eppendorf tubes $(1,5 \mathrm{ml})$ (RatioLab). The tubes were subjected to UV sterilization in a laminar flow microbiological hood -class II, to remove any possible contaminants from previously handling. 1-2 colonies were collected with a sterile microbiological loop and immersed in the Chelex reagent. They were used following extraction temperatures: $57^{\circ} \mathrm{C}$ - 30 minutes, $94^{\circ} \mathrm{C}-5$ seconds using a thermoblock..

The last step included a high speed centrifugation (14,000 rot / min.) for one minute.

The amplification was conducted using a Thermocycler which has the ability to heat and cool samples in repetitive steps. PCR MasterMix(25 $\mu \mathrm{l})$ included: 1X PCR DNA dye, 2,5 mM MgCI2, 5 pmol from each primer, dNTP each at $200 \mathrm{uM}, 2,5$ U of Taq DNA polymerase (Promega, Madison, WI, USA) şi 100 ng genomic DNA.

PCR reaction in the termocyler was made in the following conditions: $94^{\circ} \mathrm{C}$ for 3 minutes, followed by 35 cycles at $94^{\circ} \mathrm{C}$ for 30 secondes, $50^{\circ}-68{ }^{\circ} \mathrm{C}$ for $30 \mathrm{sec}, 72^{\circ} \mathrm{C}$ for 1 minute and the final step elongation at $72^{\circ} \mathrm{C}$ for $7 \mathrm{~min}$. The same protocol was used to identify the toxicity genes of verotoxigenic E.coli.

The PCR used to identify Escherichia coli are presented in Table 1.

The agarose gel used for the migration of the amplified DNA samples had a concentration of $2,5 \%$ si $2 \%$, for coloring and visualization of the products EvaGreen $(1.7 \mu \mathrm{l}-35 \mathrm{ml} / \mathrm{gel} ; 7 \mu \mathrm{l}-140$ $\mathrm{ml} /$ gel) was used. The migration of the samples in the gel was done by using an electrophoresis device programmed with a power of $70 \mathrm{~V}$ and $100 \mathrm{~V}$ 


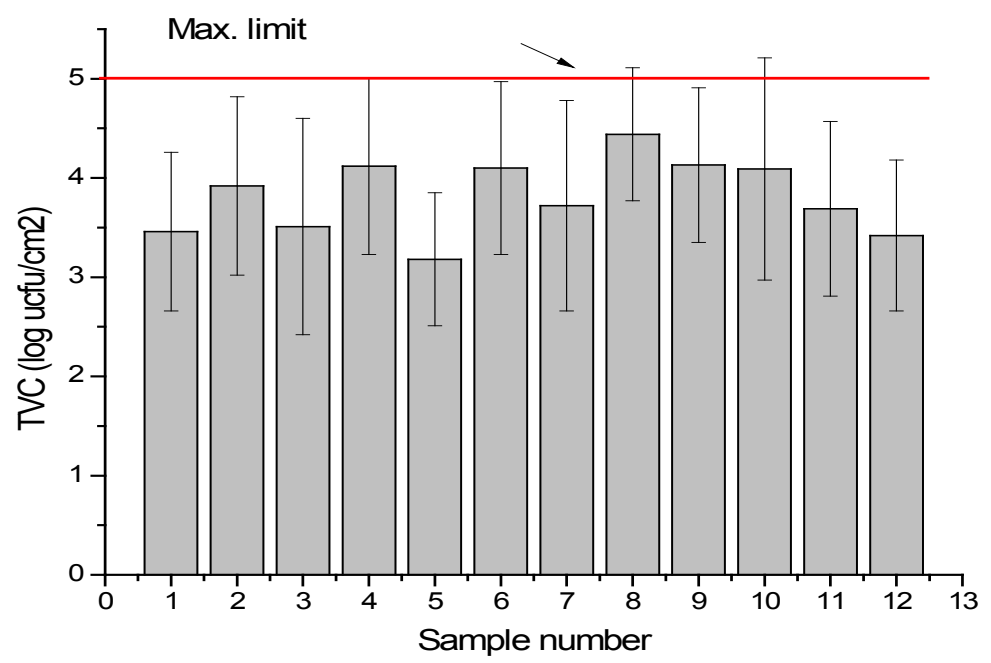

Fig. 1. The total viable count in the analyzed swine carcasses in 2015

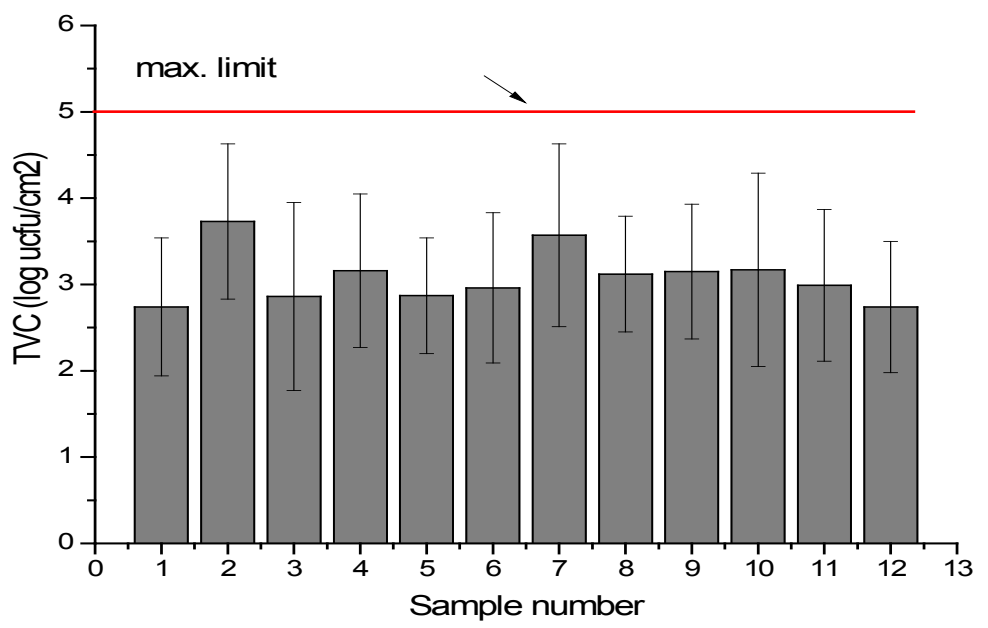

Fig. 2. The total viable count in the analyzed swine carcasses in 2016

for one hour. Reading and interpreting the results was performed using a BioRad transiluminator.

The results were analyzed statistical and mathematical using the Origin 8.5 program, using the ANOVA test.

\section{RESULTS AND DISCUSSION}

The results obtained on microbial load and configuration on the surface and depth of carcasses is largely dependent on strict compliance with the rules of hygiene throughout the processing flow of carcasses.

Analyzing the graphic in Fig. 1 shows that the average logarithmic of the total viable count in meat samples taken in 2015 from the carcasses show relatively similar values between $3.18 \pm 1.23$ $\log \mathrm{cfu} / \mathrm{cm}^{2}$ in May and $4.44 \pm 0.63 \log \mathrm{cfu} / \mathrm{cm}^{2}$ recorded in August of the same year.

The value for TVC in samples taken from the carcasses, in 2016 were similar to those in 2015, ranging from a minimum of $2.74 \pm 0.36 \mathrm{log}$ cfu / $\mathrm{cm} 2$ in January and December and a maximum $3.73 \pm 1.13 \log \mathrm{cfu} / \mathrm{cm} 2$ recorded in February, without showing significant differences between the samples processed in the studied period ( $p>0.05$ ) (Fig. 2).

By analyzing graph from Fig. 1 and 2 it can be noticed that none of the examined samples exceeded the maximum limit allowed of $5.0 \mathrm{log} \mathrm{cfu}$ / $\mathrm{cm}^{2}$ (Reg. (CE) 1441/2007).

Results regarding surface contamination of swine carcasses with germs from Enterobacteriaceae fam. are shown in the graphs in Fig. 3 and 


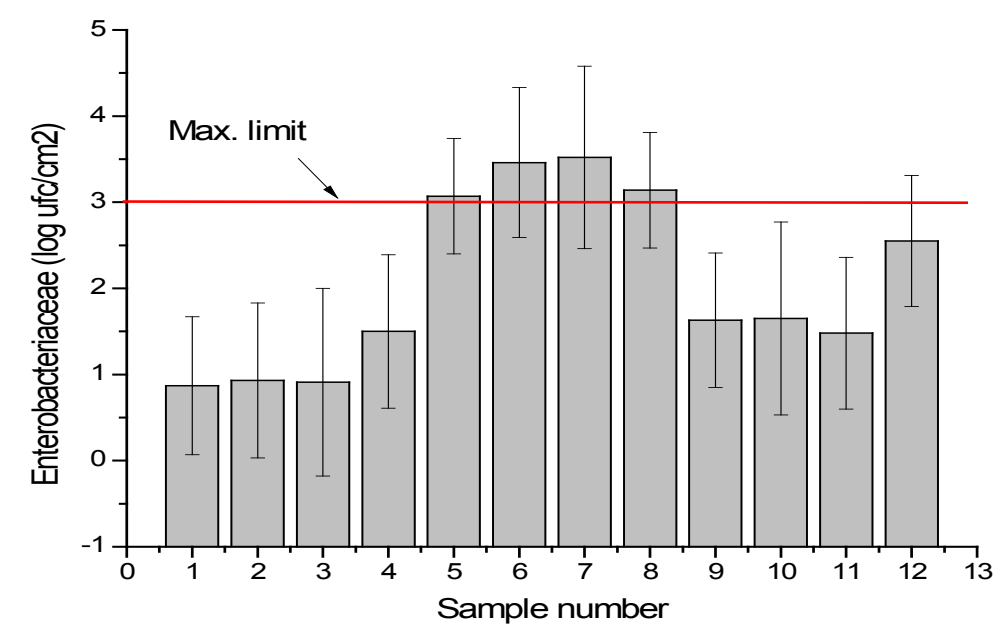

Fig. 3. The Enterobacteriaceae load in the swine carcasses examined in 2015

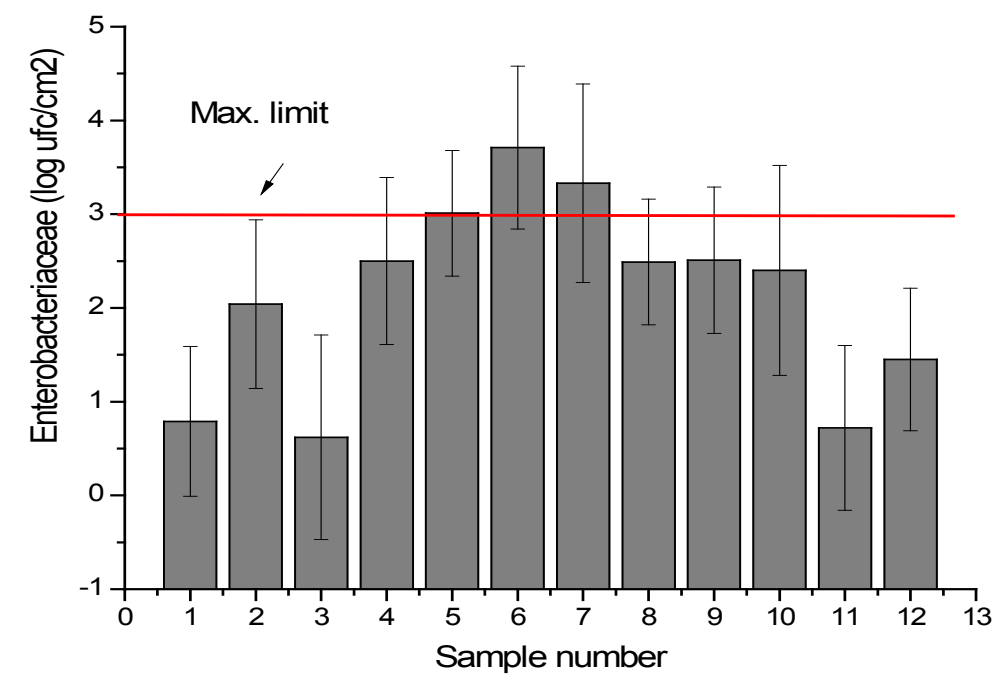

Fig. 4. The Enterobacteriaceae load in the samples examined in 2016 from the swine carcasses

4. From their analysis, it was observed that the results for samples examined in 2015 show have an average value for Enterobacteriaceae count was from $0.87 \pm 0.1 \log \mathrm{cfu} / \mathrm{cm}^{2}$ in January and a maximum of $3.52 \pm 0.06 \mathrm{log} \mathrm{cfu} / \mathrm{cm}^{2}$ in July (Fig. 3 ). Of the 40 samples examined 12 samples (30 $\%)$ were non-compliant, exceeding the maximum limit allowed of $3.0 \mathrm{log} \mathrm{cfu} / \mathrm{cm}^{2}$. Regarding the obtained results for samples from internal muscles, taken from the carcasses this showed an average for Enterobacteriaceae count slightly lower, ranging from a minimum of $0.62 \pm 0.07 \mathrm{log}$ $\mathrm{cfu} / \mathrm{cm}^{2}$ in January and a maximum of $3.71 \pm 0.18$ $\log \mathrm{cfu} / \mathrm{cm}^{2}$ in June, 9 samples having a higher value than the maximum limit (25\%) (Fig. 4).
It was also found that the noncompliant values for Enterobacteriaceae count were detected during the range May to August, which indicates a failure of Good Hygienic Practices (GHPs) and Good Manufacturing Practices (GMPs) by operators from the slaughtering unit taken study, as well as higher values of temperature within the processing spaces that can be associated with ambiental temperature.

We can appreciate that the level is lower for internal muscle samples analyzed, the differences ranging from $0.5 \log \mathrm{cfu} / \mathrm{cm}^{2}$ and $2.7 \log \mathrm{cfu}$ $/ \mathrm{cm}^{2}$. These lower values may be due to more advanced technological processes that reduce the number of germs on the surface of carcasses at very low levels, so in the evisceration and cutting 


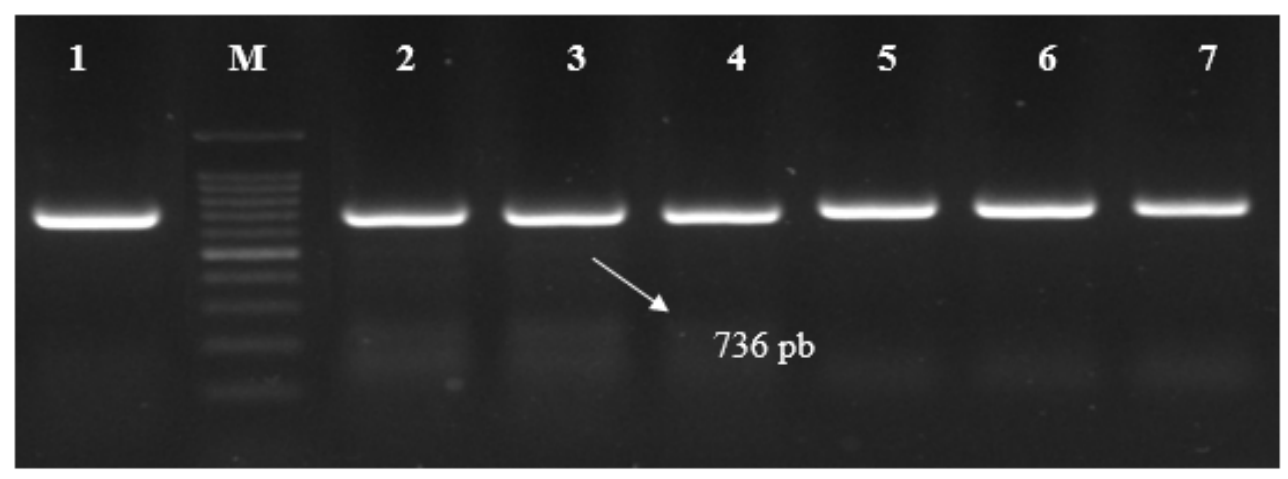

Fig. 5. The electrophoretic profile of the $736 \mathrm{bp}$ coresponding to the E.coli bacteria. 1 - positive control sample, M- ethalon scale (100 pb); 2-7: isolated samples from the identified pork samples

process, contamination of the muscle tissue is carried only through the section tools, respectively contamination with intestinal contents where the digestive tract is sectioned accidentally 3.2-3.7 log $\mathrm{cfu} / \mathrm{cm}^{2}$ (Bolton şi Pearce, 2002; Warriner, 2002). Lower levels of microbes on the pig carcasses as compared to the cattle can be explained by the fact that the head section and therefore the esophagus is not carried out, which in this case is not properly tied can result in massive contamination of the area cervical. Also, the fact that the evisceration of the GI mass is performed in block pigs, while in cattle is performed separately, is necessary to conduct an additional sections at the pylorus, which in the case of non-compliance with GHP can lead to an increased level of microorganisms of the Enterobacteriaceae family.

Similar results to those obtained in our study were obtained by Phouth et al. (2006), in order to evaluate the level of contamination with microorganisms carcasses of pigs $(n=62)$, subject to normal slaughter in slaughterhouses in Laos. The authors reported values between 4.4-4.9 log $\mathrm{cfu} / \mathrm{cm}^{2} \mathrm{TVC}$, with an average of $4.70 \log \mathrm{cfu} / \mathrm{cm}^{2}$. The total value of Enterobacteriaceae was between 2.1 and $3.3 \log \mathrm{cfu} / \mathrm{cm}^{2}$, with an average of 2.98 $\log \mathrm{cfu} / \mathrm{cm}^{2}$. Different results have been obtained by Algino et al. (2009), in small slaughterhouses from the US, where the values for TVC and Enterobacteriaceae were below the $1.0 \mathrm{log} \mathrm{cfu} /$ $\mathrm{cm}^{2}$.

Following the analysis of the results was found that from all samples $(n=40)$ examined, 36 were compliant $(85.7 \%)$ and in 6 samples was identified the presence of $E$. coli $(14.28 \%)$.
After the isolation using conventional methods, confirmation was performed by the molecular method PCR using pathogen-specific primers, shown in the previous section, for identifying pathogenic strains and toxicity gene. The results confirmed that six of the total isolates belonged to the genus E.coli (Fig. 5).

The presence of $E$. coli bacteria in the carcasses investigated it is not alarming, being a bacteria that can be found naturally in the digestive tract. What would cause concern would be the presence of pathogenic strains producing toxin. Molecular testing for the presence of toxicity genes (Stx1, Stx2) confirmed that none of these isolates showed positivity.

\section{CONCLUSION}

In conducted study was concluded that from the carcasses of pigs were obtained non-compliant results regarding germs from Enterobacteriaceae fam., the values found exceeded allowable limits for $29.16 \%$ of all samples examined during the period under study, which shows deficiencies regarding the hygiene requirements.

In what regards the molecular testing for the confirmation of $E$. coli, a total of 6 samples were positive, but none of this tested positive for the presence of the toxicity genes (Stx1, Stx2).

\section{REFERENCES}

1. Algino RJ, Badtram GA, Ingham BH, Ingham SC (2009). Factors associated with Salmonella prevalence on pork carcasses in very small abattoirs in Wisconsin, J Food Prot 72, 714-721.

2. Blanco JE, Blanco M, Alonso MP, Mora A, Dabhi G, Coira MA, Blanco J (2004). Serotypes, virulence genes, and intimin types of Shiga toxin (verotoxin)-producing Escherichia coli isolates from human patients: Prevalence 
in Lugo, Spain, from 1992 through 1999. Journal of Clinical Microbiology, 42, 311-319.

3. Blanco M, Blanco JE, Mora A, Rey J, Alonso JM, Hermoso M, Alonso MP, Dabhi G, Gonzales EA, Bernardez MI, Blanco J (2003). Serotypes, virulence genes, and intimin types of Shiga toxin (verotoxin)-producing Escherichia coli isolates from healthy sheep in Spain. Journal of Clinical Microbiology, 41, 1351-1356.

4. Bolton DJ, Pearce RA, Sheridan JJ, Blair IS, McDowell DA, Harrington D (2002). Washing and chilling as critical control points in pork slaughter hazard analysis and critical control point (HACCP) systems., J Appl Microbiol.;92(5):893-902.

5. Bonardi S, Salmi F, Riboldi E (2008). Detection and count of Salmonella enterica in pork and poultry meat products. Vet Res Commun 32(Suppl 1), S 315-317.

6. Carr TR, Kauffman RG, Meeker DL, Meisinger DJ (1997). Factors reducing pork value. Pork Industry Handbook, PIH-135. Purdue University Cooperative Extension Service, West Lafayette, 1-4.

7. Malorny B, Paccassoni E, Fach P, Bunge C, Martin A, Helmuth R 2004. Diagnostic real-time PCR for detection ofSalmonella in food. Applied and EnvironmentalMicrobiology 70, 7046-7052.
8. Phouth I, Srikitjakarn L, Kyule M, Zessin KH, Baumann M, Douangngeun B, Fries R (2006). Microbial contamination of pig carcasses at a slaughterhouse in Vientiane capital, Lao PDR. The Southeast Asian Journal of Tropical Medicine and Public Health; 37(6): 1237-41.

9. Warriner K, Aldsworth TG, Kaur S, Dodd CE (2002). Cross-contamination of carcassesand equipment during pork processing. Journal of Applied Microbiology, 93(1), 169-177. 1431J.H. Smid et al. / Meat Science 96 (2014) 1425-1431.

10. ${ }^{* * *}$ Regulamentul (CE) nr.1441/2007 al Comisiei din 5 decembrie 2007 de modificare a Regulamentului (CE) nr. 2073/2005 privind criteriile microbiologice pentru produsele alimentare.

11. *** SR EN ISO 6579/2003, SR EN ISO 6579 AC/2009. Metoda orizontală pentru detectarea bacteriilor din genul Salmonella.

12. *** SR EN ISO 4833/2003. Metoda orizontală pentru enumerarea microorganismelor. Tehnica de enumerare a coloniilor la $300 \mathrm{C}$.

13. *** SR ISO 21528-2/2007. Metoda orizontală pentru enumerarea germenilor din familia Enterobacteriaceae 